\section{B A Institute of \\ YK Business Administration

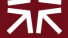 \\ Karachi \\ Leadership and Ideas for Tomorrow}

Business Review

Volume 10 Issue 1 January - June 2015

$1-1-2015$

\title{
Impact of board characteristics and audit committee on financial performance: A study of manufacturing sector of Pakistan
}

\author{
Arfan Ali \\ Government College University, Faisalabad, Pakistan \\ Saad Bin Nasir \\ Government College University, Faisalabad, Pakistan
}

Follow this and additional works at: https://ir.iba.edu.pk/businessreview

Part of the Accounting Commons, Business Analytics Commons, Finance Commons, and the Industrial Organization Commons

\section{c) (i)}

This work is licensed under a Creative Commons Attribution 4.0 International License.

\section{Recommended Citation}

Ali, A., \& Bin Nasir, S. (2015). Impact of board characteristics and audit committee on financial performance: A study of manufacturing sector of Pakistan. Business Review, 10(1), 102-114. Retrieved from https://doi.org/10.54784/1990-6587.1317

This article is brought to you by iRepository for open access under the Creative Commons Attribution 4.0 License and is available at https://ir.iba.edu.pk/businessreview/vol10/iss1/9. For more information, please contact irepository@iba.edu.pk. 


\title{
ARTICLE
}

\section{IMPACT OF BOARD CHARACTERISTICS AND AUDIT COMMITTEE ON FINANCIAL PERFORMANCE: A STUDY OF MANUFACTURING SECTOR OF PAKISTAN}

\author{
Arfan Ali \\ Government College University, Faisalabad, Pakistan. \\ Saad Bin Nasir \\ Government College University, Faisalabad, Pakistan.
}

\begin{abstract}
The research will examine the role of corporate governance (CG) practices on firm's financial performance. Population of this research will be manufacture sector of Pakistan. For the purposes of measurement of impact of corporate governance practices such as board size, board independence, CEO/chairman duality and audit committee will take as independent variables and for the measurement of firm's performance return on assets and return on equity will take as dependent variables. Panel data regression model will used to estimate the impact of CG on firm performance.
\end{abstract}

Key Words: Board Size, Board Independence, CEO/Chairman Duality, Audit Committee, $R O A$ and $R O E$

\section{Introduction}

Corporate Governance can be defined in a variety of ways; generally it is a system or mechanism by which organizations are controlled. It includes the set of rules and regulations that affect the decisions of managers and distribution of rights and duties among all stakeholders of the corporation such as boards, managers, shareholders and other stakeholders. Corporate governance is considered as a system by which managers are held responsible for corporate conduct and performance. Corporate governance deals with mechanisms by which stakeholders of a corporation exercise control over corporate insiders and management such that their interests are protected(Dar, Naseem, Niazi, \& Rehman, 2011).

According to (López de Silanes, La Porta, \& Shleifer, 1999) corporate governance is "a set of mechanisms with the help of which outsiders safeguard themselves against expropriation by the insiders. Insiders include both managers and controlling shareholders".

Numerous studies have investigated the connection between corporate governance and firm performance (Black, Jang, \& Kim, 2006; Klapper \& Love, 2004; Yermack, 1996) with mixed results. There is little evidence of a systematic relationship between the characteristics of the board(Bhagat \& Black, 2001). (Anderson \& Reeb, 2003) observed a positive relationship between corporate governance and firm performance but (O'Connell \& Cramer, 2010) found a negative relationship between them. A key component in governance mechanisms is the role of the board of directors. The board of directors monitors the management and set the strategic direction for the organization. The board of directors reviews and ratifies proposals given by management, and board is the primary and dominant internal corporate governance mechanism in the organization(Brennan, 2006) 
Efficient corporate governance contributes to the sustainable economic advantage by increasing the performance of corporations and increasing their access to outside capital. In new emerging markets corporate governance serves a number of public policy objectives. It reduces vulnerability of the financial crises, reduces transaction cost, capital cost and leads to market development. Corporate governance concerns the relationship among the management, board of directors, controlling shareholders, minority shareholders and other stakeholders(Dar et al., 2011).

Pakistan is one of few countries that had adopted a code of corporate governance. It was issued and finalized by Security Exchange commission of Pakistan (SECP) in March, 2002. After this, it was incorporated in all the listed companies of three stock exchanges of Pakistan i.e. Karachi Stock Exchange, Lahore Stock Exchange and Islamabad Stock Exchange.

In this study board size, board composition and ceo/chairman duality will be taken as the corporate governance mechanisms and on the other hand it is also necessary the selection process of appropriate performance measure is also impartial. Most studies used a variety of financial measures. For this study researcher will consider Return on asset and return on equity as the financial performance measure (Dar et al., 2011; Lam \& Lee, 2012; Mollah, Al Farooque, \& Karim, 2012; Ujunwa, 2012; Yasser, 2011).

\section{Significance}

In this research, performance of the firm will be analyzed through corporate governance because corporate governance in Pakistan is at its initial stage. So, proper application of corporate governance and its practice is not streamlined in Pakistan yet. Therefore, this research will establish an empirical relationship of corporate governance and its effects on the corporate performance. Corporate governance is an indispensable element for firm's performance as well as the growth of the economy of country. This research is going to be conduct in the manufacturing sector of Pakistan. It will helpful for any sector to gain competitive edge by implication of corporate governance practices in the company, also to maximize performance of the firm. Further it will facilitate the policy makers to take appropriate measures to ensure effective implementation of corporate governance practices in Pakistan.

\section{Objectives}

To find out the effect of board size on financial performance.

To measure the impact of board composition on financial performance.

To evaluate the effect of CEO/chairman duality on financial performance.

To calculate the effect of audit committee on financial performance

To define the areas of improvement in manufacturing sector regarding corporate governance.

\section{Literature review}

According to Paul, Friday, and Godwin (2011)board composition and corporate performance do not have significant relationship with each other and decided that firm performance cannot be enhanced by increasing the number of Non-Executive directors in the board. 
Lam and Lee (2012) in their study concluded that ceo/chairman duality has a significant but negative impact on firm performance (ROE and ROA). But the nominated board has a positive and significant impact on ROE.

While conducting a study Brennan (2006) founded that board size and ROA are positively related. At the same time board composition don't have significant relationship with firm performance. They stated that CEO duality and firm performance are negatively related.

Joh (2003), in their study investigated that board composition has a negative relation with firm performance. They suggested that CEO duality should not be there for better firm performance.

Ponnu (2008) found that non-executive directors were positively associated with profitability. Mollah et al. (2012) concluded that "if non-executive directors resulted in effective monitoring, their effectiveness would increase in line with their board representation. Lam and Lee (2012) described that firms with higher numbers of outside directors on the board had a greater return on equity than the board with executive directors.

Heenetigala and Armstrong (2011)concluded that duality of CEO has a negative impact of firm's performance. Their study showed that one person at two positions is not a desirable situation for an organization. 2002 Moore suggests that separating the role of chairman and CEO. This situation often creates conflicts because BOD's is to monitor the CEO. In case of duality there must be misuse of power and chances of corruption may increase. Heenetigala and Armstrong (2011) founded that Ceo/chairman duality is negatively related to firm performance.

According to Lam and Lee (2012)Board of directors is the most influential aspect of corporate governance as they are responsible to plan and decide for the company. It is the board of directors that prevents the company and stakeholders from the conflict of interest in order to enhance the financial performance of the firm. Decision about board size is a critical area of concern for company as it affects performance a lot. Board effectiveness can be measured by different parameters such as size, structure, duality and part in ownership.

Dar et al. (2011) described that, Board of directors is the central point of corporate governance practices that plays a significant role in the implementation of corporate governance practices in the company. Board size is negatively correlated with firm's financial performance because when the size of board of directors increases the problems of communication and coordination increases No doubt small size increases the efficiency but firms also lose the benefits of diversity in terms of experiences and knowledge.

Ujunwa (2012) described that CEO duality is negatively associated with firm. This finding is consistent with the agency theory which posits that board duality promotes CEO entrenchment by reducing board monitoring effectiveness and impedes firm performance. her is significant negative relationship between board size and performance. This implies that as the size of a firm's board increases, the less the degree of its impact on the financial performance on the firm.

Heenetigala and Armstrong (2011) Concluded that independent board are having greater ROA as compared to companies having dependent board, which as a result is show greater firm's performance. Companies having independent are having greater ROE as compared to companies having dependent board, which as a result is showing greater firm's performance. 


\section{Theoretical framework}

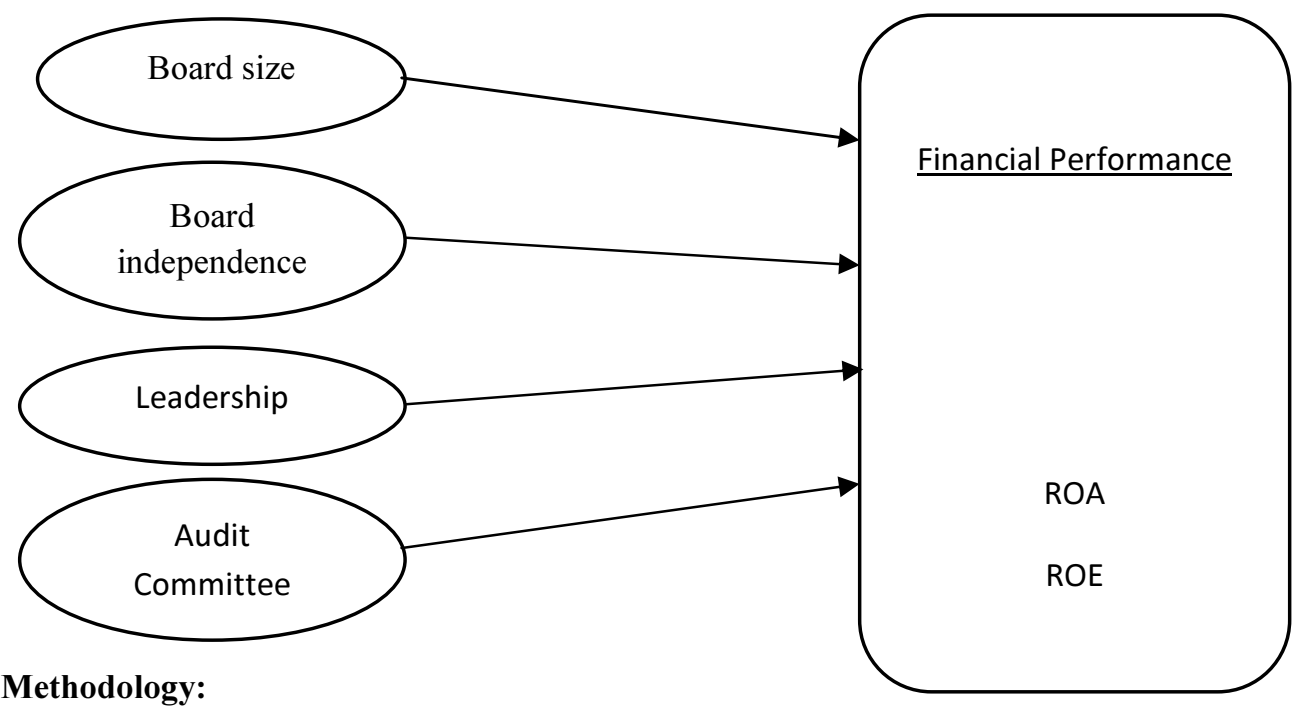

In this part definition of the variables, model, and all the measures that will use to determine the role of corporate governance on firm's performance. Target population for this research will be manufacturing sector of Pakistan; Sample size for this study will be chemical, pharmaceutical, sugar, cement, leather, paint and steel industries in Pakistan. Data for the corporate governance mechanism and financial performance will collect form annul audited reports of companies over the year of 2007 to 2011 . The years 2007 to 2011 selected because this study seeks to examine the post effect of the implementation of Code of Corporate Governance issued in 2002.

Further data will collect from following sources:

$>$ Audited financial reports published by companies and available on the websites of corporate.

State bank of Pakistan's reviews about the performance manufacturing sector of Pakistan.

$>$ Publications by KSE about firm's performance.

> Publications by Pakistan institute of corporate governance.

Panel data regression model will use for the purpose of data analysis. As our data will be cross sectional and time series data that is why we are using panel data approach to conduct our research and to find out results. T-test will apply to cheek the validity of results obtained from regression model. F-test will apply to cheek the impact of all the independent variables on dependent variable. Weather all independent variables as whole have some impact on dependent variable or not? Coefficient of determination (R2) will tell us how much variation occurs in dependent variable (firm performance) due to change in independent variables (corporate governance mechanisms). 
Variables

\begin{tabular}{|l|l|}
\hline Variables & Definition \\
\hline Independent variables & \\
\hline Board size & total number of members in the board of directors \\
\hline Board independence & \% of non-executive director to executive directors \\
\hline Leadership & Value (0) if no duality and (1) if duality exist. \\
\hline Audit Committee & Operating committee of the Board of Directors. \\
\hline Dependent variables & \\
\hline Return on assets & Net income / book value of total assets \\
\hline Return on equity & Net income /shareholders equity \\
\hline
\end{tabular}

\section{Analytical Technique}

The characteristics of the sample was cross-sectional and time, the regression model of panel data has been applied to the effects of the characteristics of the board of control of the financial performance of the company. This study used panel data regression for autocorrelation of variables to eliminate time-series heteroskedasticity want to know heterogeneity

Here in this study is time-series and cross-section as the data and the regression model of panel data were used for analysis and to determine the effect of governance mechanisms on firm performance. There are other names for the panel data, such as pooled data (pooling of time series and cross-sectional observations), combination of time series and cross-section data, micro-panel data, and longitudinal data (an extension the study of a variable or a group of subjects (Gujarati, 2003).

In previous studies (Yermack 1996, Villalonga and Amit 2006, Abor and Biekpe 2007, Pucheta - Martínez and De Fuentes 2007, Di Pietra, Grambovas et al. 2008, Ehikioya 2009) regression model of panel data and found that the use of the regression model of panel data to measure a good fit of the relationship between governance mechanisms and strong financial performance of the company.

There are some advantages of panel data. In this study, the panel data concern the company over time, the heterogeneity is related to that information. Regression techniques of panel data, this heterogeneity into account specific individual variables. The combination of cross-sectional and time-series observations, data more informative panel offers more variety, less collinearity among the variables.

Panel data in a better way that just does not minimize the effects in pure or pure time-series cross data. It biasness were caused by separated at the company data are large aggregates (Gujarati) can be used divided are observed can be measured.

In this study, descriptive statistics were used to determine the average value of different variables. The reason for using descriptive statistics to determine whether to make the various listed on the Karachi Stock Exchange, a significant difference in the variable depending on the type of business and a better explanation of the relationship between corporate governance and financial performance. 
Companies can t-test was also used for the validity of the audit results of the regression model. F-test of the effect of the independent variable to control the dependent variable. Of all the independent variables as a whole have certain effects on the dependent variable or not?

\section{Statistical Model}

The statistical model developed for this study, to investigate. On a sound financial performance, the effect of boards of variables is a statistical model for relations between variables in the form of mathematical equations that shows how a variable to make other variables statistically related.

Overall, two regression models with panel data developed two dependent variables in this study were used, and a model for each variable, two models developed for the sample.

The statistical model for this study is as follow:

$\mathrm{Y}=\beta \square+\beta 1 \mathrm{G}+\varepsilon$

Where in equation (1) " $Y$ " is dependent variable representing firm performance; Return on asset, Return on equity and Net profit margin. " $\beta \square$ " is constant " $\beta 1$ " is coefficient of explanatory variable (corporate governance mechanisms) and " $G$ " is explanatory variables; Board Size (BSIZE), Board Independence (BINDPN), and Leadership (LSHIP). " $\mathcal{E}$ " is error term, it is assumed to remain constant and have zero mean over the time.

Model will rewrite separately for both performance measures of firm which is being measure by ROA and ROE.

$\mathrm{ROA}=\alpha+\mathrm{b} 1(\mathrm{BSIZE})+\mathrm{b} 2(\mathrm{BINDPEN})+\mathrm{b} 3(\mathrm{LISHIP})+\mathrm{b} 4(\mathrm{AUDCOM})+\mathrm{e} \ldots \ldots$.
$\mathrm{ROE}=\alpha+\mathrm{b} 1(\mathrm{BSIZE})+\mathrm{b} 2(\mathrm{BINDEPN})+\mathrm{b} 3(\mathrm{LISHP})+\mathrm{b} 4(\mathrm{AUDCOM})+\mathrm{e} . . .$.

Where:

$\mathrm{ROA}=$ Return on Asset

$\mathrm{ROE}=$ Return on Equity

AUDCOM= Audit Committee

BSIZE $=$ Board Size

BINDEPN $=$ Board Independence

$\mathrm{LSHIP}=\mathrm{CEO} /$ chairman duality

$\mathrm{e}=$ error term

\section{Research Hypothesis}

Hypothesis of this research are as following:

Board size:

Hol:b1 $=0$

Board size has no impact on firm performance.

$\mathrm{Hal}: \mathrm{b} 1 \neq 0$

Board size has some impact on financial performance 
Board independence:

Ho2:b2=0

Board independence has not any significant impact at firm's performance.

$\mathrm{Ha} 2: \mathrm{b} 2 \neq 0$

Board independence has significant impact at firm's performance.

Leadership :

Ho3: $b 3=0$

Leadership does not affect firm performance

Ha3: $\mathrm{b} 3 \neq 0$

Leadership is a causal factor of firm performance

Audit Committee

Ho4: $\mathrm{b} 4=0$

AUDC has not any significant impact at firm's performance.

$\mathrm{Ha} 4: \mathrm{b} 4 \neq 0$

$\mathrm{AC}$ has some impact on financial performance

\section{Results}

\section{Panel data regression analysis:}

The multiple regression analysis with the panel data provides the evidence of the effect of corporate governance and firm financial performance.

\subsubsection{Rerun on Asset as performance indicator:}

Table 4.1

Descriptive Statistics

\begin{tabular}{|c|c|c|c|}
\hline & MEAN & MINIMUM & MXIMUM \\
\hline ROA & 14.347 & -30.54 & 63.72 \\
\hline BSIZE & 8.70 & 7.00 & 15.00 \\
\hline DUAL & .625 & .00 & 1.00 \\
\hline BCOMP & .467 & .25 & .90 \\
\hline AUDTCOM & .73 & .50 & 1 \\
\hline
\end{tabular}


Table 4.2

Pooled OLS Regression

Coefficients

\begin{tabular}{|c|c|c|}
\hline Variables & Coefficients & t-value \\
\hline (Constant) & $\begin{array}{l}-21.557 \\
(7.918)\end{array}$ & -2.722 \\
\hline BSIZE & $\begin{array}{l}1.985 \\
(.568)\end{array}$ & $4.782 * * *$ \\
\hline DUAL & $\begin{array}{c}-.164 \\
(2.353)\end{array}$ & -.070 \\
\hline BCOMP & $\begin{array}{c}19.643 \\
(5.519)\end{array}$ & $3.559 * * *$ \\
\hline AUDCOM & $\begin{array}{c}13.059 \\
(7.651)\end{array}$ & $1.707^{*}$ \\
\hline R Square & \multicolumn{2}{|c|}{.132} \\
\hline F-statistic & \multicolumn{2}{|c|}{$7.424 * * *$} \\
\hline
\end{tabular}

4.2.1 Rerun on Equity as performance indicator

Table 4.3

Descriptive Statistics

\begin{tabular}{|c|c|c|c|}
\hline & MEAN & MINIMUM & MXIMUM \\
\hline ROE & 30.57 & -28.96 & 72.87 \\
\hline BSIZE & 8.70 & 7.00 & 15.00 \\
\hline DUAL & .625 & .00 & 1.00 \\
\hline BCOMP & .467 & .25 & .90 \\
\hline AUDTCOM & .73 & .50 & 1 \\
\hline
\end{tabular}


Table 4.4

\section{Pooled OLS Regression}

Coefficients

\begin{tabular}{|c|c|c|}
\hline Variables & Coefficients & t-value \\
\hline (Constant) & $\begin{array}{l}-74.622 \\
(27.065)\end{array}$ & -2.722 \\
\hline BSIZE & $\begin{array}{c}5.393 \\
(1.940)\end{array}$ & $2.779 * * *$ \\
\hline DUAL & $\begin{array}{l}14.272 \\
(8.044)\end{array}$ & $1.774^{*}$ \\
\hline ВСОМР & $\begin{array}{c}32.221 \\
(18.864)\end{array}$ & $1.708^{*}$ \\
\hline AUDCOM & $\begin{array}{c}46.859 \\
(26.151)\end{array}$ & $1.792 *$ \\
\hline R Square & \multicolumn{2}{|c|}{.089} \\
\hline F-statistic & \multicolumn{2}{|c|}{$5.860 * * *$} \\
\hline
\end{tabular}

\section{Discussion}

Results indicate that on average return on asset of each company in sample is 14.347 $\%$. Return on equity of each firm on average is $30.57 \%$. on average each firm has a board size of 9 board members with a $6.5 \%$ non-executive directors on board. It means that on average each board with 9 members contains 4 non-executive directors.

From the descriptive statistics it is being clear that, $62.5 \%$ firms in total sample practice separate leadership style in which chair of CEO and Chairman is held separately by two different persons. Similarly on average audit committee of each firm contain $73 \%$ nonexecutive directors committee.

\section{Board Size}

Board size has significant positive impact on the performance of firm with both performance indicators or return on asset and return on equity. Value of coefficients for both return on asset and return on equity are 1.985 and 5.393 respectively. This impact is highly significant at $1 \%$ level.

Based on these results this study accepts hypothesis H1a for manufacturing firms is accepted and H1o is rejected. From these results it is being clear that board size has significant positive explanatory power to influence the all firm performance measures. The result regarding the relationship between board size and firm performance supports the view 
of (Cheng, 2008; Dwivedi \& Jain, 2005; Georgiou, 2010; Larmou \& Vafeas, 2010; Pearce \& Zahra, 1992; Rashid, 2009; Sanda et al., 2005; Yasser et al., 2011).

The reasons of positive impact of board size on firm performance may be that, Boards with large size are expected to have representation of people with diverse backgrounds and they are expected to bring knowledge, wider perspective and intellectuals to the board (Mollah et al., 2012). The large board size is a helpful governance mechanism to control the management. It may provide more effective monitoring of the current activities of the company (Georgiou, 2010; Perry \& Shivdasani, 2005)

Large boards have lower variability of financial performance due to the fact that large boards tend to make less extreme decisions through consensus and this leads to less variation in performance (Cheng, 2008).

\section{CEO and Chairman Duality}

Separate leadership style has significant positive impact on the performance of firm with both performance indicators. Coefficients for both return on asset and return on equity are -.164 and 14.272 respectively. This impact is significant at $10 \%$ level with return on equity only but not statistically significant with return on equity; indicating that separate leadership of firm will increase the performance of firm.

Based on these results this study accepts hypothesis $\mathrm{H} 2 \mathrm{a}$ for manufacturing firms is accepted and $\mathrm{H} 2 \mathrm{o}$ is rejected. The results of separate leadership are in line with the results of some previous studies of (Braun \& Sharma, 2007; Ehikioya, 2009; Kajola, 2008; Ponnu, 2008; Sanda et al., 2005; Yermack, 1996).

The probable reasons of positive impact of separate leadership are that; the separate leadership is the best option for the roles of chairman and CEO. It will help the board to be in a position to monitor the management. The role of board of directors in any firm is to supervise or monitor the work of management. Head of management is chief executive officer or CEO and head of board of director is Chairman. If the seat of CEO and Chairman is held by same individual, then the true essence of monitoring role of board could not be played successfully. That is why separate leadership leads to increase in performance of firm (Georgiou, 2010).

Separate leadership is encouraged in the context of agency theory; implying that Duality leadership gives enormous power and authority to the CEO, which not only weakens the board and such a powerful CEO may affect the activities of board; such as formation of board committees in pursuant to his personal interest; manipulate the meetings of the board by not raising an important agenda It may reduce the board's ability to exercise the governance function and create a conflict between management and board that may reduce firm performance (Rashid, 2009)

\section{Board Composition}

Board composition has significant positive impact on firm performance with both performance indicators of return on asset and return on equity. Beta values indicate that return on asset and return on equity will change with 19.643 and 32.221 respectively. This impact is significant at $1 \%$ with return on asset and at $10 \%$ with return on equity. Based on these results, we accept alternative hypothesis $\mathrm{H} 3$ a for manufacturing firms is accepted and $\mathrm{H} 3 \mathrm{O}$ is rejected. 
Overall the board structure has significant impact on the performance of firm. The results of board structure variable are in consistent with the previous results of (Demb \& Neubauer, 1992; T.-y. Lam \& S.-k. Lee, 2012; Rashid, 2009; Sanda et al., 2005; Q.R. Yasser, 2011).

Reason of their positve impact on the performance of firm may be that; nonexecutive directors are competent enough to perform their tasks and they have inside information of the firm (Nicholson \& Kiel, 2007).

Non-executive directors are needed on boards to monitor and control the actions of executive directors due to their opportunistic behavior and act as the checks and balances in enhancing boards' effectiveness (Jensen \& Meckling, 1976). Additionally, non-executive directors might be considered to be "decision experts" (Fama \& Jensen, 1983), independent and not intimidated by theCEO (Weisbach, 1988), able to reduce managerial consumption of perquisites (Brickley \& James, 1987) and act as a positive influence over directors' deliberations and decisions (Pearce \& Zahra, 1992). According to the Tricker (1984) the presence of non-executive directors on boards provides "additional windows on the world". This is congruent with the resource dependence theory, which proposes that non-executives directors act as middleman between companies and the external environment due to their expertise, prestige and contacts.

\section{Audit Committee}

Audit committee has also significant positive impact on the performance of firm. Beta values with both return in asset and return on equity are 13.059 and 46.859 respectively. This impact is significant at 15 levels. Based on these results this study we accept alternative hypothesis $\mathbf{H}_{4}$ a for manufacturing firms is accepted and $\mathbf{H}_{4} \mathbf{O}$ is rejected.

These results are in line with the previous study of (Jensen, 1993; Vafeas, 1999; Q.R. Yasser, 2011). Audit committees being occupied by majority of nonexecutive directors have positive influence on the firm's performance. This is because this study shows that the strong relationship between the audit committee and the two performance measures is statistically significant. This result is consistent with some previous studies such as Klein (2002) and Mansi and Reeb (2004), they also reported strong positive relation-ship between audit committee and the performance variables they used in their studies.

\section{General Findings}

General findings of this study are;

- Board size has positive significant impact on the performance of firm.

- Non-CEO/Chairman Duality has significant positive impact on the performance of firm

- Board composition or non-executive directors on board have also significant impact on the performance of firm.

- Audit committee has also significant positive impact on the performance of firm. More non-executive directors on board have positive impact on the performance of firm. 
- All board characteristics have significant positive impact on the performance of firm.

\section{Suggestion}

On the base of this study followings are some suggestion:

$>$ Overall corporate governance has significant impact on the performance of firm so regulators should give more importance to governance issues.

$>$ Large board size is recommended for the manufacturing sector of firms listed on Karachi Stock Exchange; it will help to debate the issues in detail and large number of directors with miscellaneous background and knowledge. It will help to increase the financial performance of firm.

$>$ Separate leadership is appropriate in Pakistani context as it will helpful to protect the interest of shareholders and other stakeholders as well. Duality leadership gives vast power and authority to the CEO, which not only deteriorates the board as a proficient board. Such a powerful CEO may disturb the activities of board.

$>$ Non-executive directors on board are required on board and supportive for the observing purposes that is why they are recommended to be on the board.

$>$ Audit committee with more non-executive directors I also recommended for the improved firm performance. More representation of non-executives on the audit committee will lead toward improved check and balance on the activities of firm. 莫糈

\section{References}

Anderson, R. C., \& Reeb, D. M. (2003). Founding-family ownership and firm performance: evidence from the S\&P 500. The Journal of Finance, 58(3), 1301-1327.

Bhagat, S., \& Black, B. (2001). Non-Correlation between Board Independence and LongTerm Firm Performance, The. J. CorP. l., 27, 231.

Black, B. S., Jang, H., \& Kim, W. (2006). Does corporate governance predict firms' market values? Evidence from Korea. Journal of Law, Economics, and Organization, 22(2), 366-413.

Brennan, N. (2006). Boards of directors and firm performance: is there an expectations gap? Corporate Governance: An International Review, 14(6), 577-593.

Dar, L. A., Naseem, M. A., Niazi, G., \& Rehman, R. U. (2011). Corporate Governance and Firm Performance: A Case Study of Pakistan Oil and Gas Companies listed In Karachi Stock Exchange. Global Journal of Management And Business Research, 11(8).

Heenetigala, K., \& Armstrong, A. (2011). The Impact of Corporate Governance on Firm Performance in an Unstable Economic and Political Environment: Evidence from Sri Lanka. Available at SSRN 1971927.

Joh, S. W. (2003). Corporate governance and firm profitability: evidence from Korea before the economic crisis. Journal of Financial Economics, 68(2), 287-322. 
Klapper, L. F., \& Love, I. (2004). Corporate governance, investor protection, and performance in emerging markets. Journal of Corporate Finance, 10(5), 703-728.

Lam, T. Y., \& Lee, S. K. (2012). Family ownership, board committees and firm performance: evidence from Hong Kong. Corporate Governance, 12(3), 6-6.

López de Silanes, F., La Porta, R., \& Shleifer, A. (1999). Corporate ownership around the world. Journal of finance, 54(2), 471-517.

Mollah, S., Al Farooque, O., \& Karim, W. (2012). Ownership structure, corporate governance and firm performance: Evidence from an African emerging market. Studies in Economics and Finance, 29(4), 301-319.

O'Connell, V., \& Cramer, N. (2010). The relationship between firm performance and board characteristics in Ireland. European Management Journal, 28(5), 387-399.

Paul, A., Friday, O., \& Godwin, O. (2011). Board Composition and Corporate Performance: An Analysis of Evidence from Nigeria. Research Journal of Finance and Accounting, 2(4), 64-73.

Ponnu, C. H. (2008). Corporate governance structures and the performance of Malaysian public listed companies. International Review of Business Research Papers, 4(2), 217-230.

Ujunwa, A. (2012). Board Characteristics and the Financial Performance of Nigerian Quoted Firms. Corporate Governance, 12(5), 5-5.

Yasser, Q. R. (2011). Corporate governance and performance: An Analysis of Pakistani listed firms. Global Journal of Management And Business Research, 11(10).

Yermack, D. (1996). Higher market valuation of companies with a small board of directors. Journal of financial economics, 40(2), 185-211.

They who do not read can have nothing to think and little to say.

Dr. Johnson 